\title{
The thermal impact of the fin tilt angle and its orientation on performance of PV cell using PCM
}

\author{
Mohamed L. Benlekkam ${ }^{1,2 *}$, Driss Nehari ${ }^{1}$, Habib I. Madani ${ }^{2}$ \\ ${ }^{1}$ Laboratory of Smart Structure, Institute of Science and Technology, Centre University of Ain Temouchent, Ain Temouchent \\ 46000, Algeria \\ ${ }^{2}$ Department of Mechanical Engineering, National Polytechnic School of Oran, Oran 31000, Algeria
}

Corresponding Author Email: benlekkam.mohamed@yahoo.com

https://doi.org/10.18280/ijht.360319

Received: 20 November 2017

Accepted: 31 August 2018

\section{Keywords:}

phase change material, latent heat, thermal regulation, photovoltaic cell, $P V$ cooling

\begin{abstract}
The temperature rises of photovoltaic's cells (PV) affects its conversion efficiency. However the use of phase change material (PCM) "RT25" layer with horizontal inner fins linked to PV panel can maintain its temperature. A numerical study of a novel proposed configuration is performed; aiming to understand the effect of fins tilt angle and its orientation on thermal regulation enhancement of PV cells. The computations are based on an iterative, finite-volume numerical procedure that incorporates an enthalpy formulation for simulation of the phase change phenomenon. The comparison between the numerical predictions and numerical and experimental data from literature shows a good agreement. This study is also carried out for various tilt angles in the range of $0^{\circ}$ to $45^{\circ}$ in an interval of $5^{\circ}$ and orientation of internal fins converged or diverged. Results indicate that the fins tilt angle $\left(\alpha=25^{\circ}\right)$ can maintain the PV cell efficiency at $14 \%$ with an average temperature of $34,5^{\circ} \mathrm{C}$ for 3 hours, compared with PV/PCM system with horizontal fins $\left(\alpha=0^{\circ}\right)$ which its efficiency decrease to $12.5 \%$ from its maximal value $(15 \%)$ with an average temperature of $38^{\circ} \mathrm{C}$.
\end{abstract}

\section{INTRODUCTION}

The temperature elevation of photovoltaic cell reduces its electrical efficiency. However, only $15-20 \%$ of the sunlight received by the PV panel can be transformed into electricity, while the rest is dissipated into heat according to Emery et al. [1]. Which increase the PV operating temperature, and as a result, affects the electrical conversion efficiency and the solar cell lifetime Norton et al. [2]. This can reduce the PV cell efficiency of $0.5 \%$ per $1{ }^{\circ} \mathrm{C}$ of elevation. Therefore, maintaining the temperature of PV cells at adequate level can improve their efficiency. Several researches try to cool the PV cells by many techniques in order to remove the excess heat from the PV cells. Overall, the phase change materials (PCM) have many applications such as Building Energy Conservation and saving [3-4] or as a layer linked to a PV panel which has been an effective solution widely used to limit the temperature rise of PV cells [5-8].

Since the phase change materials are pure and combined, Farouk et al. [5] studied their influence on the performance improvement of the PV modules. They found that the use of pure $\mathrm{PCM}$ can reduce the $\mathrm{PV}$ temperature by more than $6.5^{\circ} \mathrm{C}$ by an average of $2.7^{\circ} \mathrm{C}$, and increase the electrical efficiency by an average of $3 \%$. on the other hand the combined PCM can reduce the PV temperature by an average of $5.6^{\circ} \mathrm{C}$ and improves the efficiency of the PV module by about $5.8 \%$.

Khanna et al. [6] analyzed the performance of a PV/PCM system under several operating conditions, namely, tilt angle, wind speed and direction, initial temperature and melting temperature of the PCM. Their results show that when the angle of inclination increases from $0^{\circ}$ to $90^{\circ}$ the $\mathrm{PV}$ temperature (in the PV/PCM system) decreases from $43.4^{\circ} \mathrm{C}$ to $34.5^{\circ} \mathrm{C}$, resulting in an increase of the $\mathrm{PV}$ efficiency from
$18.1 \%$ to $19 \%$. Moreover, the increase in the angle of the wind azimuth decreased the heat losses of the PV, which leads to an increase in the rate of heat extraction by the PCM. A PCM with a low melting temperature can maintain PV cells at lower temperature. Finally, they found that the most favorable PCM used will be that which has a melting temperature closer to room temperature.

The experimental and numerical studies of Huang et al. [914] was conducted under the thermal regulation of building integrated photovoltaic panel BIPV by using PCM. Starting by the first research Huang et al. [10] which, they have succeed to maintain the temperature of the PV cells under $40{ }^{\circ} \mathrm{C}$ for 80 min, with a PCM RT25 that have a melt temperature of $32^{\circ} \mathrm{C}$, then considering the low thermal conductivity of RT25 0.18 $\mathrm{W} \cdot \mathrm{m}^{-1} \cdot \mathrm{K}^{-1}$, an internal fins in Aluminum used to transport the thermal load into the PCM in order to reduce the temperature rise on PV. In other hand Huang et al. [9-14] investigated the use of inner fins in BIPV to enhance the heat transfer in PCM losing the excess heat in PCM. They have studied the effect of internal fins spacing on BIPV thermal regulation and PCM behavior, they found that the use of fins improves thermal distribution of $\mathrm{PV} / \mathrm{PCM}$ system and reduce its temperature significantly. Cellura et al. [15] studied a PV/PCM system numerically with a finite element method, they considered a pure PCM with a constant phase change temperature, they succeed to improve the performance of PV/PCM system by $20 \%$, but practically the PCMs are mixtures of paraffins that have a phase change range temperature. Moreover, Hasan et al. [16] have investigated experimentally the thermal regulation of four different configurations of building integrated photovoltaic's BIPV, at three insolations intensities by using five PCMs with different melt temperature. The minimum temperature obtained was $10^{\circ} \mathrm{C}$ for $5 \mathrm{~h}$ under 
$1000 \mathrm{~W} / \mathrm{m}^{2}$, and they found that the temperature regulation depends on the quantity of PCM and thermal conductivity of both PCM and the enclosure.

Karunesh et al. [17] they studied the effect of several parameters such as the heat transfer mechanisms, tilt angle and wind speed of PV/PCM system. When only conduction is considered, the operating temperature decreased by about $3^{\circ} \mathrm{C}$ and the solar efficiency is improved by $5 \%$, in addition the higher wind speed and the tilt angle allow a good cooling of photovoltaic panels. Stropnik et al. [7] studied both experimentally and numerically the electrical performance of PV/PCM system with the TRNSYS software, the electrical production by the photovoltaic module has been improved up to $7 \%$ for one year.

Elarga et al. [18] have developed a physical model to study the incorporation of an PCM layer on a double-facade of PV panel for three different climates, they have found that this technique can improve the conversion of solar energy into electricity independently of the climate, they concluded that the use of PCM can also increase the cooling of the building more than $20 \%$ per month. An experimental study was carried out by Nikolaos S et al. [19] to evaluate the efficacy of PCM to mitigate the influence of temperature on photovoltaic module performance. The PV/PCM system was tested under Mediterranean climatic conditions. They found that the chosen PCM "RT27" succeeded in reducing the PV module temperature by an average of $11^{\circ} \mathrm{C}$ compared to a system without PCM, furthermore the conversion efficiency of the PV module increases by about $8.6 \%$.

The impact of the fins tilt angle and its orientation on performance of $\mathrm{PV} / \mathrm{PCM}$ system has not been studied previously. Therefore, in the present paper, we investigate the effect of tilt angle in the range of $0^{\circ}$ to $45^{\circ}$ in an interval of $5^{\circ}$ and orientation of internal fins converged or diverged on the thermal regulation and electrical efficiency of $\mathrm{PV} / \mathrm{PCM}$ system. Moreover, we tested the PV/PCM in different insolation intensities low, medium and high to determine the thermal performance of the PCM used in cooling.

\section{DESCRIPTION OF THE PROBLEM}

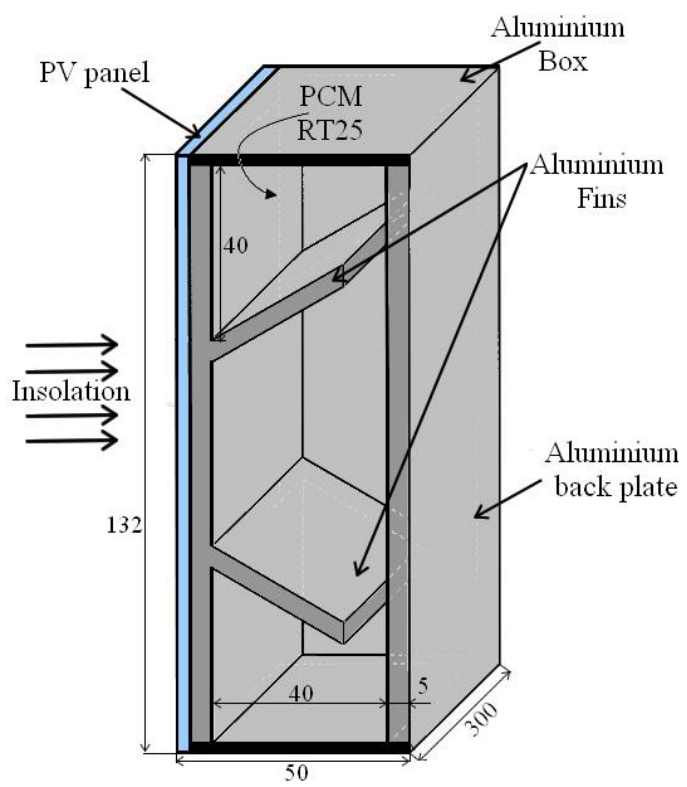

Figure 1. Schematic diagram of the numerical PV/PCM system (dimensions in $\mathrm{mm}$ )
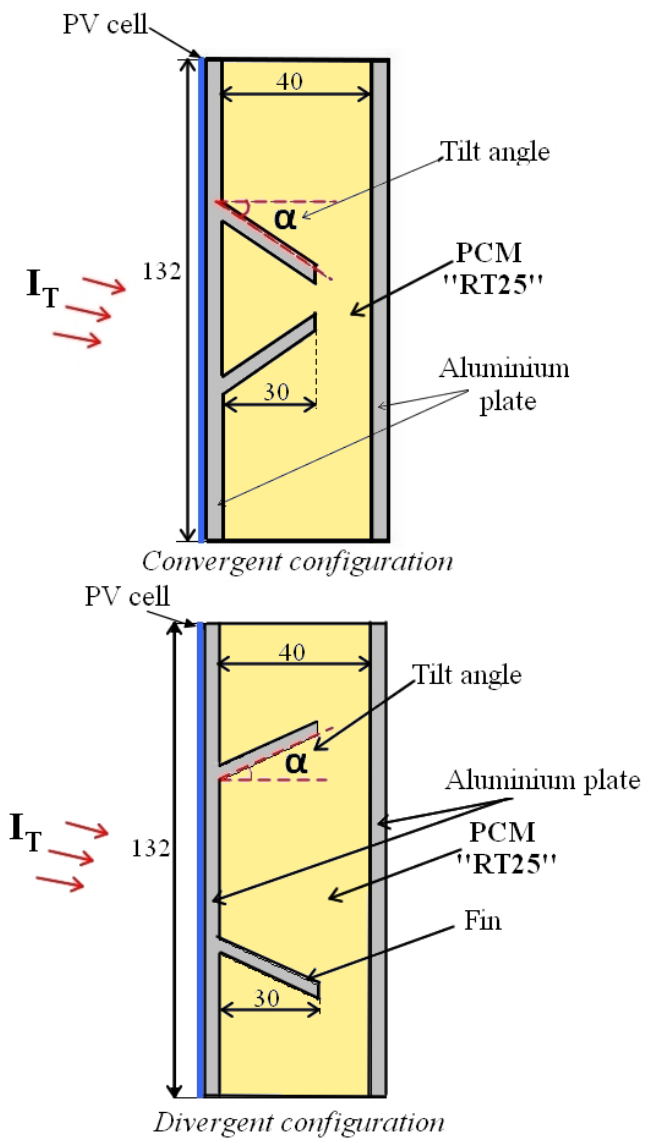

Figure 2. Physical model for numerical calculation. (dimensions in $\mathrm{mm}$ )

The schematic diagram of PV/PCM considered in this study is presented in figure 1 and figure 2 , as shown in figure the PV/PCM system is composed by a PV panel attached on a rectangular enclosure filled by PCM. The PCM used is Rubitherm RT25 and its thermophysical properties which are assumed to be constant during the melting process are provided in Table 1. Air circulates freely over the PV panel and the back wall of the container. The PCM is in direct contact with the PV panel and the back wall. The incident energy $\mathrm{I}_{\mathrm{T}}$ is absorbed and dissipated into heat inside the $\mathrm{PV} / \mathrm{PCM}$ system. In our case, we use the same geometry considered by Huang et al. [10]. Therefore, we use the same boundary and initial conditions of the last authors, which are:

The initial temperature of the system $\mathrm{PV} / \mathrm{PCM}$ is $\mathrm{T}_{\mathrm{PV}}$;

The front and rear surfaces of the system have respectively the values he $e_{1}$ and he ${ }_{2}$;

Concerning the top and bottom boundaries, the adiabatic conditions are used.

\section{GOVERNING EQUATIONS}

In the present study, a 2D implicit finite volume method was used to solve the governing equations for a head transfer conjugate with phase change process. the enthalpy-porosity formulation was adopted for solving phase change region in PCM, in this method the interface between the solid and the liquid phases modeled as a porous medium. The liquid fraction varies smoothly across this porous, so-called mushy region.

The mushy zone is modeled via the phase fractions, which are incorporated in the source terms in the governing equations to account for the phase change phenomena. 
Table 1. Thermodynamic properties of "RT25"[20], paraffin wax [21] and Aluminium [22].

\begin{tabular}{|c|c|c|c|}
\hline Property & PCM "RT25" & Paraffin wax & Aluminum \\
\hline \multicolumn{4}{|l|}{ Density } \\
\hline Solid, $\mathrm{Kg} \mathrm{m}^{-3}$ & 785 & 830 & 2675 \\
\hline Liquid, Kg.m ${ }^{-3}$ & 749 & 830 & Not used \\
\hline \multicolumn{4}{|l|}{ Specific heat capacity } \\
\hline Solid, J.m ${ }^{-3} . \mathrm{K}^{-1}$ & 1413000 & 1593600 & 2415525 \\
\hline Liquid, J.m ${ }^{-3} \cdot \mathrm{K}^{-1}$ & 1797600 & 2705000 & Not used \\
\hline \multicolumn{4}{|l|}{ Thermal conductivity } \\
\hline Solid, W. $\mathrm{m}^{-1} \cdot \mathrm{K}^{-1}$ & 0.19 & 0.514 & 211 \\
\hline Liquid, W.m ${ }^{-1} \cdot \mathrm{K}^{-1}$ & 0.18 & 0.224 & Not used \\
\hline Melting temperature, & 26.6 & 32 & Not used \\
\hline Latent heat of fusion, $\mathrm{J} \mathrm{kg}^{-1}$ & 232000 & 25000 & Not used \\
\hline
\end{tabular}

Table 2. Illustrate the different studies based on equation eq. (14) developed by evans et florschuetz [22]

\begin{tabular}{ccccc}
\hline $\mathbf{T}_{\text {ref }}\left({ }^{\circ} \mathbf{C}\right)$ & $\eta_{0}$ & $\beta_{0}\left(\mathbf{K}^{-1}\right)$ & Cell type & References \\
\hline $\mathbf{2 5}$ & 0.15 & 0.0041 & Mono-Si & Evans et al. [24] \\
\hline $\mathbf{2 5}$ & 0.12 & 0.0045 & Mono-Si & Chow T [25] \\
\hline 25 & 0.09 & 0.0045 & PV/T system & Tiwari et al. [26] \\
\hline $\mathbf{2 5}$ & 0.127 & 0.0063 & PV/T system & Tonui et al. [27] \\
\hline $\mathbf{2 5}$ & 0.12 & 0.0045 & Mono-Si & Chow TT [28] \\
\hline $\mathbf{2 5}$ & 0.15 & 0.004 & Poly-Si & Kant et al. [19] \\
\hline
\end{tabular}

The continuity

$\frac{\partial}{\partial x_{i}}\left(\rho u_{i}\right)=0$

The momentum

$\frac{\partial}{\partial \mathrm{t}}\left(\rho \boldsymbol{u}_{i}\right)+\frac{\partial}{\partial \boldsymbol{x}_{i}}\left(\rho_{\boldsymbol{u}_{j}} \boldsymbol{u}_{i}\right)=\mu \frac{\partial^{2} \boldsymbol{u}_{i}}{\partial \boldsymbol{X}_{i} \partial \boldsymbol{x}_{j}}-\frac{\partial p}{\partial \boldsymbol{x}_{i}}+\boldsymbol{s}_{i}$

The energy

$\frac{\partial}{\partial \mathrm{t}}(\rho h)+\frac{\partial}{\partial \boldsymbol{x}_{i}}\left(\rho \boldsymbol{u}_{i}^{h}\right)=\frac{\partial}{\partial \boldsymbol{x}_{i}}\left(k \frac{\partial T}{\partial \boldsymbol{x}_{i}}\right)+\boldsymbol{S}_{h}$

where $\rho$ is the density, $k$ denotes the thermal conductivity, $\mu$ is the dynamic viscosity, $S_{\mathrm{i}}$ and $\mathrm{S}_{\mathrm{h}}$ are the source terms, $\mathrm{u}_{\mathrm{i}}$ is the velocity component in the i-direction, $x_{i}$ is a Cartesian coordinate, and $h$ is the specific enthalpy. The sensible enthalpy $h_{s e}$ is given by:

$h_{s}=h_{0}+\int_{T_{0}}^{T} C_{p} d T$

And the total enthalpy, $H$ is defined as

$$
H=h_{s e}+\Delta H
$$

where $\Delta H=\gamma \mathrm{L}$ is the enthalpy change due to phase change, $\mathrm{h}_{0}$ is the reference enthalpy at the reference temperature $T_{0}, C p$ is the specific heat, $\mathrm{L}$ is the specific enthalpy of melting (liquid state) and $\gamma$ is the liquid fraction during the phase change which occur over a range of temperatures. $\mathrm{T}_{\text {solidus }}<\mathrm{T}<\mathrm{T}_{\text {Liquidus }}$ defied by the following relations:

If $\mathrm{T}<\mathrm{T}_{\text {solidus }}$

$$
\gamma=\frac{\Delta H}{L}=0
$$

$$
\text { If } \mathrm{T}_{\text {solidus }}<\mathrm{T}<\mathrm{T}_{\text {liquidus }}
$$

$\gamma=\frac{\Delta H}{L}=\frac{T-T_{s}}{T_{l}-T_{s}}$

$$
\text { If } \mathrm{T}>\mathrm{T}_{\text {Liquidus }} \quad \text { (liquid state) }
$$

$\gamma=\frac{\Delta H}{L}=1$

The source terms $S_{i}$ and $S_{h}$ are given by:

$S_{i}=-A(\gamma) u_{i} \frac{C(1-\gamma)^{2}}{\gamma^{3}+\varepsilon} u_{i}$

$S_{h}=\rho L \frac{\partial \gamma}{\partial t}$

where $\mathrm{A}(\gamma)$ is defined as the "porosity function" which governs the momentum equation based on Carman-Kozeny relationship for flow in porous media. The function reduces the velocities gradually from a finite value of 1 in fully liquid to 0 in fully solid state within the computational cells involving phase change. The epsilon $\varepsilon=0.001$ infinity avoidance constant due to division by zero and $\mathrm{C}$ is a constant reflecting the morphology of the melting front where $\mathrm{C}=10^{5}$.

Boussinesq approximation was adopted to calculate the change in PCM density as a function of temperature in the liquid density given by:

$\rho=\rho_{0}\left[1-\beta\left(T-T_{0}\right)\right]$

And the relationship of buoyancy forces in the momentum equation is given by: 


$$
-\rho g=\rho_{0} g\left[\beta\left(T-T_{m}\right)-1\right]
$$

where $\rho_{0}$ is the reference density at melting temperature $T_{m}$ and $\beta$ is the thermal expansion.

The temperature of the PV cell $\left(\mathrm{T}_{\mathrm{pv}}\right)$ can vary depending on the weather variables such as ambient temperature $\left(T_{a m}\right)$, local wind speed $\left(V_{w}\right)$, solar radiation $\left(\mathrm{I}_{\mathrm{t}}\right)$, physical properties of the system such as glazing Skoplaki et al. [21]. The effect of temperature on the electrical efficiency of a PV cell can be obtained by using a fundamental equation: Kant et al. [15].

$\eta_{c}=\eta_{0}\left(1-\beta_{0}\left(T_{c-} T_{0}\right)\right)$

where $\eta_{0}$ and $\beta_{0}$ are the reference solar cell efficiency and the solar cell temperature coefficient at the standard operating temperature of $25^{\circ} \mathrm{C}$, respectively. The reference solar irradiance It is equal to $1000 \mathrm{~W} / \mathrm{m}^{2}$. These values are provided by the manufacturer data sheet and are available for most PV cells.

\section{NUMERICAL MODELING}

The governing equations are solved by using the commercial code Fluent 6.3.26. The pressure-velocity coupling is accounted by using SIMPLE algorithm Patankar [27], whereas the Quick scheme was adopted for convective discrimination. The Boussineq approximation was adopted to take account the change in density of the PCM in liquid phase as a function of temperature.

A variable time step with a minimum value of $0.01 \mathrm{~s}$ are used for all the simulations, and the convergence was confirmed at each time step, with the convergence criterion of $10^{-6}$ for all variables. The grid size adopted in present simulation was $48 \times 132$ using mesh generation software ANSYS GAMBIT 2.4.6.

\subsection{Validation}

All the simulations were conducted using the heat transfer coefficients on the front and rear surfaces are respectively $12.5 \mathrm{~W} \cdot \mathrm{m}^{-2} \cdot \mathrm{K}^{-1}$ and $7.5 \mathrm{~W} \cdot \mathrm{m}^{-2} \cdot \mathrm{K}^{-1}$ and the insolation was $750 \mathrm{Wm}^{-2}$.

The present model Benlekkam et al [30] was validated successfully with numerical and experimental data of Huang et al. [10]. Our validation was performed with the same initial and boundary conditions, material properties and geometry, then we compared our results with the predicted and experimental temperature evolution of front and rear surface of PV/PCM system Figure 3, in addition we compared the isothermal contours of temperature in Figure 4. A good agreement was obtained.

\section{RESULTS AND DISCUSSION}

\subsection{Effect of the orientation of fins for a PV/PCM system}

For a better understanding of the thermal load distribution in a PV/PCM system. Several researchers use metallic fins with high thermal conductivity through the PCM to transport the heat that occurs on the PV at the core of the PCM. The obtained results show that the cooling rate of the PV panel. increases. Consequently, we suggested to study the orientation of fins for different tilt angles $\left(\alpha=10^{\circ}, 30^{\circ}\right.$ and $\left.45^{\circ}\right)$ which could improve the thermal regulation of the PV panel.

The Figure 5, shows the comparison between the average temperature versus time of the front surface of the PV/PCM system for two orientations (converged and diverged) Figure 2. It is clearly visible according to Figure 5, that the temperature has minimum value for the configuration in which the two fins are diverged with a tilt angle of $10^{\circ}$ and $30^{\circ}$, since the latter ensure a good distribution of the thermal loads in the $\mathrm{PV} / \mathrm{PCM}$ system, whereas the converged fins configuration serves to concentrate the heat comes from the PV panel in the center of the PV/PCM system.

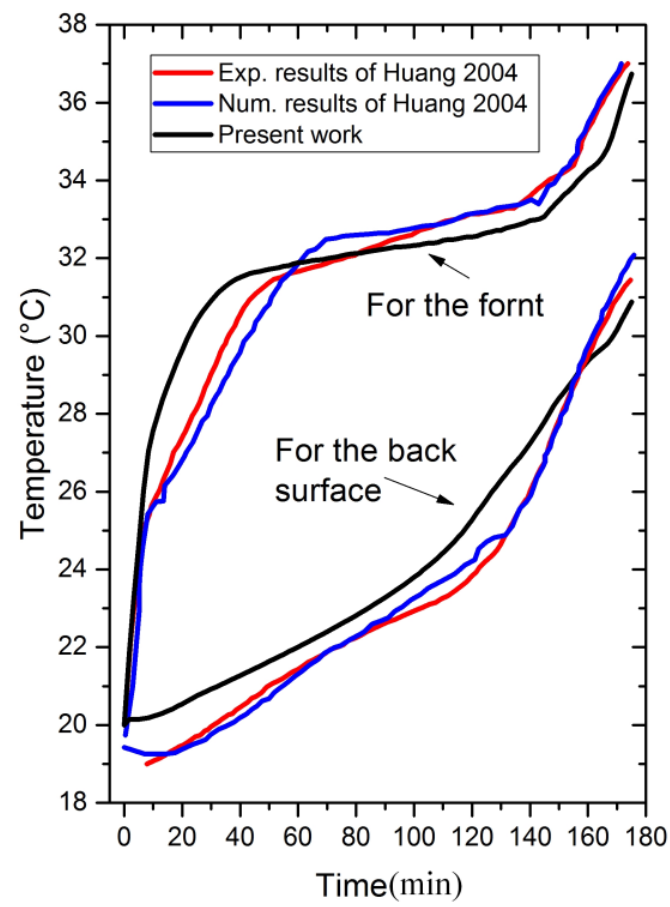

Figure 3. Model validation with Huang et al. [10]

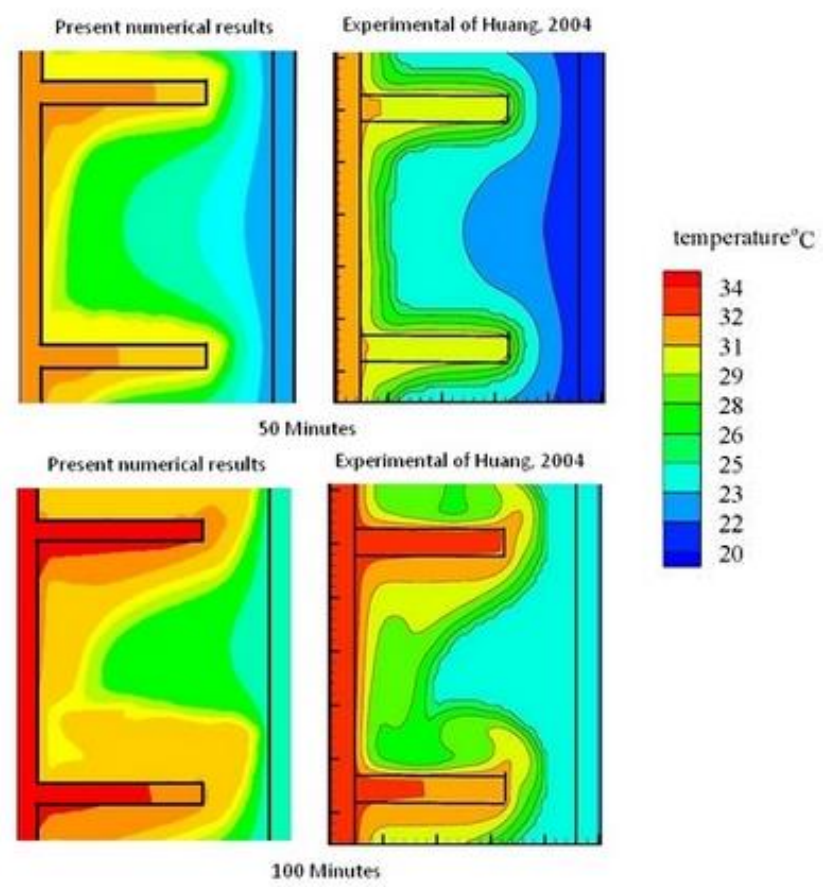

Figure 4. Model validation for Predicted isothermal counter for the PV/PCM system after 50 and 100 minutes 
Which causes an increase of the PV temperature to $38.5^{\circ} \mathrm{C}$ at the 170th minute, and subsequently affects the efficiency of the PV panel. However, the temperature reaches at $34^{\circ} \mathrm{C}$. for diverged fins configuration with $\alpha=30^{\circ}$. This very large deviation of $4.5^{\circ} \mathrm{C}$ allowed us to widen our investigation on the system whose fins are diverged for several tilt angles to determine the optimum angle, which gives a good thermal regulation.
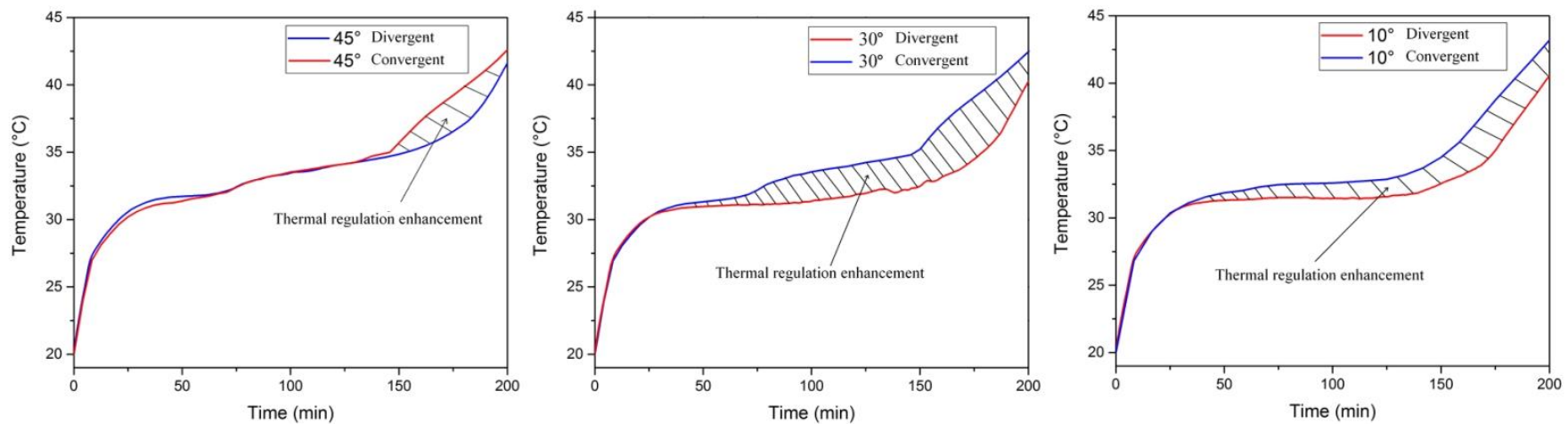

Figure 5. Average temperature evolution on PV front for three tilts angle $\alpha=10^{\circ}, 30^{\circ}$ and $45^{\circ}$.

\subsection{Effect of tilt angle for PV/PCM system with diverged fins}

A parametric study was carried out to evaluate the effect of fins tilt angle on the cooling rate of PV cell, this evaluation was performed by the variation of tilt angle $\alpha$ to take the values $\left[0^{\circ}, 5^{\circ}, 10^{\circ}, 15^{\circ}, 20^{\circ}, 25^{\circ}, 30^{\circ}, 35^{\circ}, 45^{\circ}\right]$ respectively. All calculations were performed along the 200 minutes until the PCM was completely melted us shown in figure 5 .

The figures 6-a and 6-b shows the isothermal contours at the 50th and 100th minute of the configurations studied. It can be seen that the temperature of the PV registers a large deviation at the 100th minute for the system, which $\alpha=25^{\circ}$, it is $1.5^{\circ} \mathrm{C}$ by comparison with the systems which $\alpha=0^{\circ}$ and $\alpha=45^{\circ}$, and this difference increases until the temperature of the PV reaches at $34^{\circ} \mathrm{C}$ for $\alpha=25^{\circ}$ after the $175^{\text {th }} \mathrm{mn}$. On the other hand, it exceeds $36,5^{\circ} \mathrm{C}$ for the horizontal fin system $\left(\alpha=0^{\circ}\right)$.

The same behavior of PCM was recorded. However, the evolution of the front temperature of the configurations under investigation records a minimum value of $30.8^{\circ} \mathrm{C}$ for $\alpha=25^{\circ}$ and another maximum of $33.5^{\circ} \mathrm{C}$ for the system where $\alpha=45^{\circ}$. This large deviation of $2.5{ }^{\circ} \mathrm{C}$ in the $100^{\text {th }}$ minute can be justified by the cold molten PCM for the configurations which $\alpha=10^{\circ}, 15^{\circ}, 20^{\circ}, 25^{\circ}$ and $30^{\circ}$, so this latter provides a good thermal load distribution via the cold molten PCM flow.

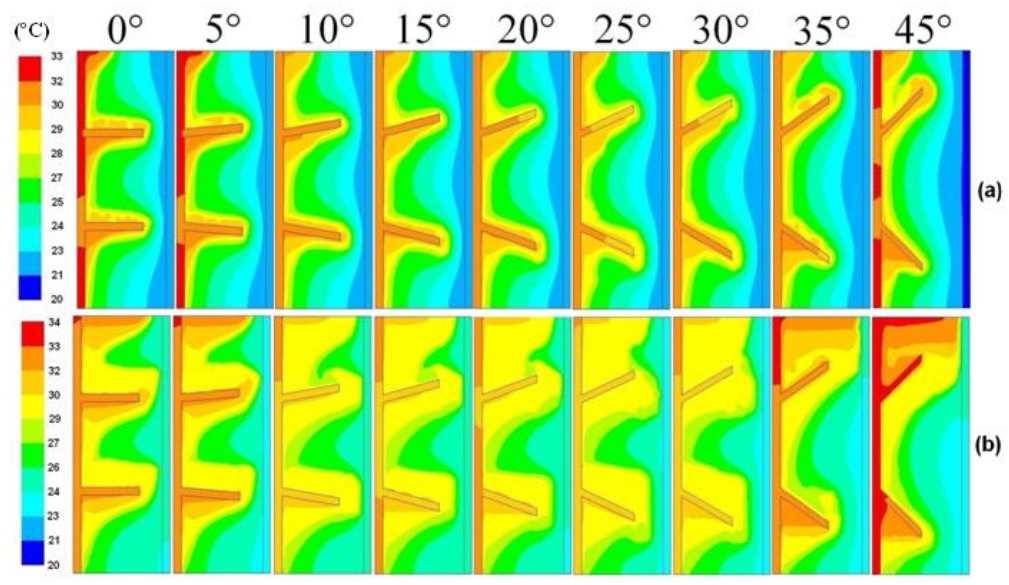

Figure 6. Predicted isothermal contours of PV/PCM system at: (a) the 50th and (b)100th minute

However, the other systems concentrate heat in specific regions, and create a hot quantity of liquid PCM, which increases the temperature of PV panel.

The figure 7, illustrates the cooling rate of the PV panel due to the angles of inclination used in the present work, the system with $\alpha=25^{\circ}$ allows a good regulation which is $3{ }^{\circ} \mathrm{C}$ with respect to the system with horizontal fins $\alpha=0^{\circ}$, this result represents a high cooling rate.

The PV/PCM system with inclined fins of $\alpha=25^{\circ}$ has been exposed to several intensities of irradiation flux (500, 750 and $1000 \mathrm{~W} / \mathrm{m}^{2}$ ), to evaluate their effect on the thermal behavior of the PCM cooling in three different climates.

Figure 8 and 9 shows the contours of the liquid fractions of the PV/PCM system recorded at 50, 100, 150 and 200 minutes and its average temperature evolution versus time.

The temperature rise of PV/PCM system under the three irradiation intensities was rapid up to $30^{\circ} \mathrm{C}$ according to the figure 9; due to the sensible heating of the solid PCM by domination of conduction heat transfer. this is indicated by the almost uniform liquid-solid interface figure 8 at 50 minutes, and when the temperature of the PCM layer in direct contact with the rear surface of the PV reached its melting point, the thermal energy absorbed as latent heat. Therefore the temperature rise gradient decreased and the temperature of the $\mathrm{PV}$ is maintained.

Once the solid-liquid melting front propagates; in this 
moment, the heat transfer is dominated by convection in the molten PCM.

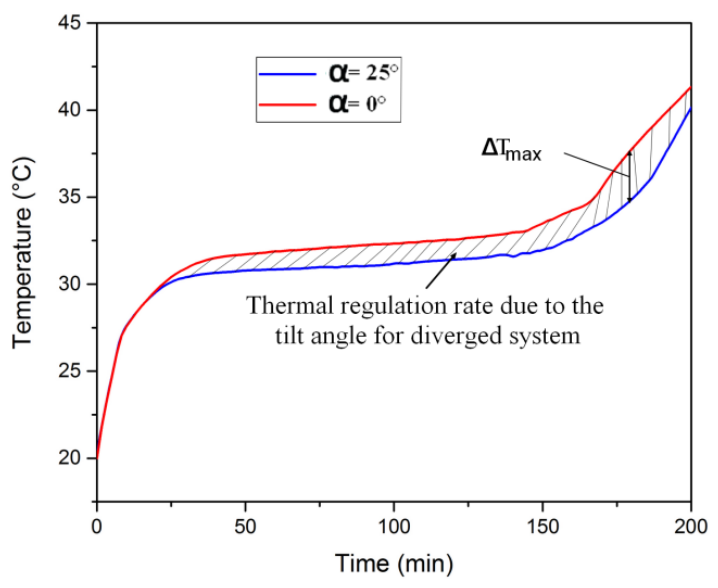

Figure 7. Average temperature on the front surface of reference system $\alpha=0^{\circ}$ and the system with $\alpha=25^{\circ}$

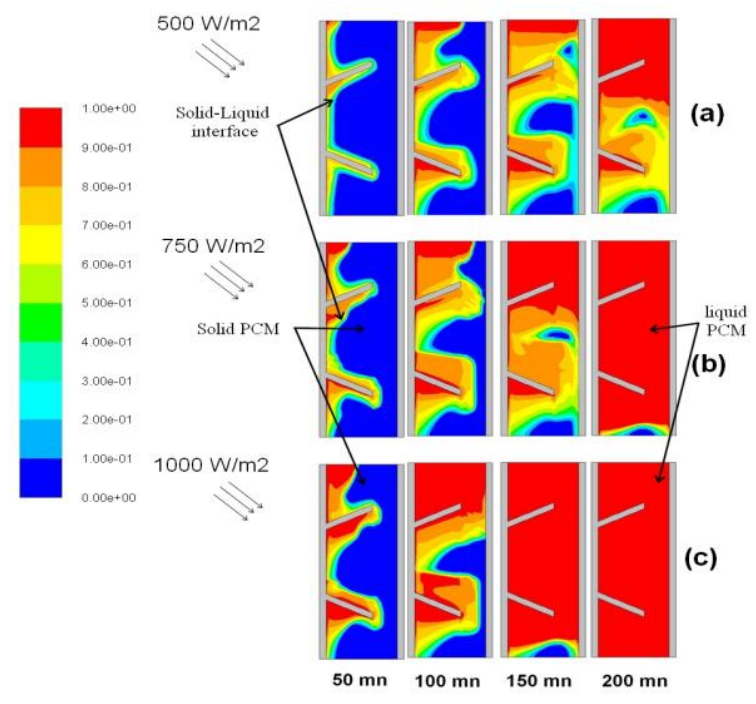

Figure 8. Liquid fraction contours of the PV/PCM system under: (a) $500 \mathrm{~W} / \mathrm{m}^{2}$, (b) $750 \mathrm{~W} / \mathrm{m}^{2}$ and (c) $1000 \mathrm{~W} / \mathrm{m}^{2}$

As the time elapsed, the thickness of the melting PCM layer increases and triggers the natural convective flow as shown in figure 8 at $150 \mathrm{~min}$, which force the liquid PCM to move upward, near the aluminum front wall (hot wall). then cool the PV cell by absorbing the excess thermal energy as latent heat.

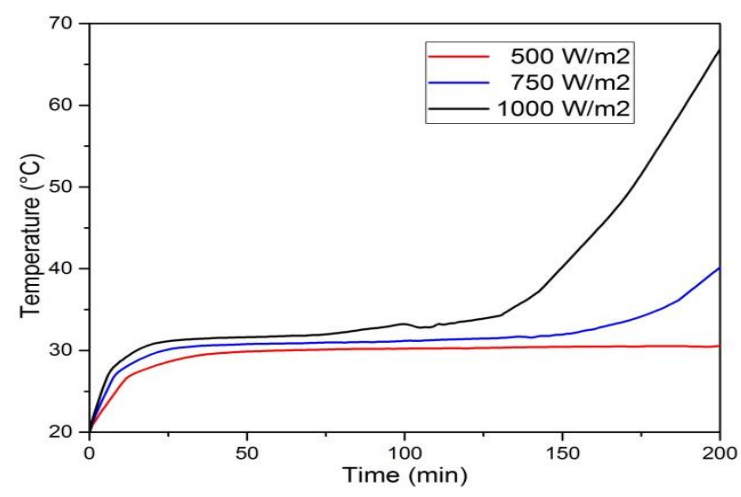

Figure 9. Temperature evolution of PV/PCM system under three intensities levels
It is clear from figure 8, that the PCM melted rapidly when the PV/PCM system is exposed under $1000 \mathrm{~W} / \mathrm{m}^{2}$, because its temperature increases rapidly compared with the rest system, which receives a low heat flux. Under a heat flux of 500, 750 and $1000 \mathrm{~W} / \mathrm{m}^{2}$, the PCM takes 250 minutes, 200 minutes and 150 minutes respectively to be completely melted. The temperature of the $\mathrm{PV}$ was maintained at $32^{\circ} \mathrm{C}$ for more than $200 \mathrm{mn}$ under a heat flux of $500 \mathrm{~W} / \mathrm{m}^{2}$. On the other hand, it is $40^{\circ} \mathrm{C}$ and $67^{\circ} \mathrm{C}$ for the same period under an irradiation flux of 750 and $1000 \mathrm{~W} / \mathrm{m}^{2}$ respectively.

Then, our PCM is very useful under low thermal irradiation "less than $750 \mathrm{~W} / \mathrm{m}^{2}$ " and an ambient temperature of $20^{\circ} \mathrm{C}$. As the insolation intensity increases, the temperature of the PV panel increases and the melting time of the PCM decreases.

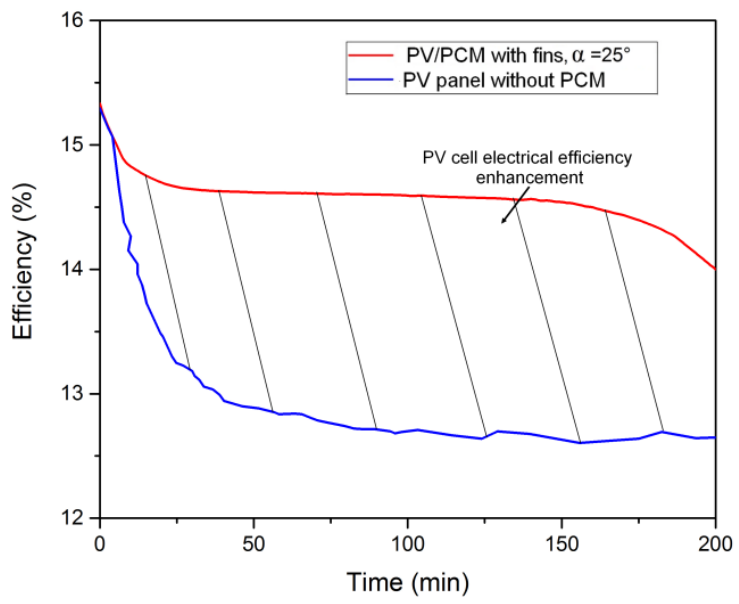

Figure 10. The PV cell electrical efficiency with and without PCM layer

The transient variation in electrical efficiency of solar cells for the PV/PCM systems is shown in figure 10. The efficiency of the PV cells is calculated by the equation Eq (14).

From Figure 10, it can be seen that the temperature rise of the PV cells was negatively affects its efficiency. This latter decreases with time until the melting state is reached; so it decreases from its maximum value $15 \%$ at ambient temperature, to $14 \%$ for a PV/PCM system with fins which $\alpha$ $=25^{\circ}$ and to $12.6 \%$ for a PV panel without PCM layer, for 200 minutes.

The use of PCM can maintain the efficiency of PV cells at an average value greater than $14.6 \%$ more than 3 hours; a drop of $1 \%$ compared to the maximum efficiency of the PV cells used (15\%). However, the PV cells efficiency without a PCM layer exposed under the same thermal conditions fall of $2.5 \%$ of its maximum value because of the elavation of the temperature.

\section{CONCLUSION}

Numerical simulations of thermal and electrical performance of a PV/PCM system with internal fins was achieved successfully. The developed numerical model was compared with numerical and experimental data of literature for both: Average temperature of PV cells versus time and the isothermal contours for $50^{\text {th }}$ and $100^{\text {th }}$ minutes, where a good agreement was found.

The effect of fins tilt angle and its orientations on the thermal regulation rate of PV/PCM system were studied. 
Also, the PCM performance is evaluated under different insolation intensities. Based on the findings of the present computational study of the PV/PCM system, the following conclusions are drawn:

Comparing the fins orientations of PV/PCM system, the best results were obtained with diverged configuration that maintained the temperature about $34^{\circ} \mathrm{C}$ for 170 minutes, while the converged maintained its at $38^{\circ} \mathrm{C}$.

The results achieved showed that the fins tilt angle with diverged configuration less than $30^{\circ}$ allows a good thermal cooling rate, and maintained the PV cell efficiency at average value of $14 \%$ for more than 3 hours compared with PV system without PCM.

The diverged configuration of PV/PCM system with fins tilt angle $25^{\circ}$, provide the best performances.

It was found that the PCM "RT25" was more useful for thermal regulation of PV/PCM system under medium and low insolations intensities for the same thermal operating conditions.

\section{ACKNOWLEDGMENT}

The authors address the sincerest thanks to the directorate general for scientific research and technological development for its financial support under the FNRSDT/DGRSDT within the framework of ERANETMED3 (Project ERANETMED3166 EXTRASEA).

\section{REFERENCES}

[1] Emery KB, Caiyem J, Dunlavy Y, Field D, Kroposki H, Moriarty B, Ottoson T, Rummel L, Strand S. (1996). Temperature dependence of photovoltaic cells, modules and systems. The 25th IEEE Photovoltaic Specialists Conference. Washington, DC, USA. http://dx.doi.org/10.1109/PVSC.1996.564365

[2] Norton B, Eames PC, Mallick TK, Huang MJ, McCormack SJ, Mondol JD, Yohanis YG. (2011). Enhancing the performance of building integrated photovoltaics. Solar Energy 85(8): 1629-1664. http://dx.doi.org/10.1016/j.solener.2009.10.004

[3] Zheng Y. (2017). Study on phase change energy storage materials in building energy saving. Chemical Engineering Transactions 62: 523-528. https://doi.org/10.3303/CET1762088

[4] Liu X. (2017) Preparation and application of multicomponent composite phase change materials in building energy conservation. Chemical Engineering Transactions 62: 529-534 https://doi.org/10.3303/CET1762088

[5] Hachem F, Abdulhay B, Ramadan M, El Hage H, El Rab M G, Khaled M. (2017). Improving the performance of photovoltaic cells using pure and combined phase change materials-Experiments and transient energy balance. Renewable Energy 107: 567-575. https://doi.org/10.1016/j.renene.2017.02.032

[6] Khanna S, Reddy K, Mallick TK. (2017). Performance analysis of tilted photovoltaic system integrated with phase change material under varying operating conditions. Energy 133: 887-899. http://dx.doi.org/10.1016/j.energy.2017.05.150

[7] Rok S, Stritih U. (2016). Increasing the efficiency of PV panel with the use of PCM. Renewable Energy 97: 671679. https://doi.org/10.1016/j.renene.2016.06.011

[8] Stritih U. (2016). Increasing the efficiency of PV panel with the use of PCM. Renewable Energy 97: 671-679. https://doi.org/10.1016/j.renene.2016.06.011

[9] Huang MJ. (2011). Two phase change material with different closed shape fins in building integrated photovoltaic system temperature regulation. Proceedings of the 2011 World Renewable Energy Congress, Sweden. Linköping, pp. 2938-2945. http://dx.doi.org/10.3384/ecp110572938

[10] Huang MJ, Eames P, Norton B. (2004). Thermal regulation of building-integrated photovoltaics using phase change materials. International Journal of Heat and Mass Transfer 47(12): 2715-2733. http://dx.doi.org/10.1016/j.ijheatmasstransfer.2003.11.0 15

[11] Huang MJ, Eames P, Norton B. (2006). Phase change materials for limiting temperature rise in building integrated photovoltaics. Solar Energy 80(9): 1121-1130. http://dx.doi.org/10.1016/j.solener.2005.10.006

[12] Huang MJ, Eames PC, Norton B, Hewitt NJ. (2011). Natural convection in an internally finned phase change material heat sink for the thermal management of photovoltaics. Solar Energy Materials and Solar Cells 95(7):

$1598-1603$ http://dx.doi.org/10.1016/j.solmat.2011.01.008

[13] Huang MJ, Eames PC, Norton B, Hewitt NJ. (2008). The effect of phase change material crystalline segregation on the building integrated photovoltaic system thermal performance. Proceedings of the 2008 World Renewable Energy Congress, pp. 1338-1343.

[14] Huang MJ. (2011). The effect of using two PCMs on the thermal regulation performance of BIPV systems. Solar Energy Materials and Solar Cells 95(3): 957-963. https://doi.org/10.1016/j.solmat.2010.11.032

[15] Cellura M, Brano VL, Marvuglia A. (2008). A Photovoltaic panel coupled with a phase changing material heat storage system in hot climates. 25th Conference on Passive and Low Energy Architecture.

[16] Hasan A, McCormack SJ, Huang MJ, Norton B. (2010). Evaluation of phase change materials for thermal regulation enhancement of building integrated photovoltaics. Solar Energy 84(9): 1601-1612. http://dx.doi.org/10.1016/j.solener.2010.06.010

[17] Kant K, Shukla A, Sharma A, Biwole PH. (2016). Heat transfer studies of photovoltaic panel coupled with phase change material. Solar Energy 140: 151-161. https://doi.org/10.1016/j.solener.2016.11.006

[18] Elarga H, Goia F, Zarrella A, Dal Monte A, Benini E. (2016). Thermal and electrical performance of an integrated PV-PCM system in double skin façades: A numerical study. Solar Energy 136: 112-124. https://doi.org/10.1016/j.solener.2016.06.074

[19] Savvakis N, Tsoutsos T. (2016). Phase change materials in photovoltaics: The assessment of system performance in the present Mediterranean climate conditions. In book: Power Systems, Energy Markets and Renewable Energy Sources in South-Eastern Europe 3: 219-234. https://doi.org/10.22618/TP.EI.20163.389019

[20] Rubitherm ${ }^{\circledR}$ Technologies GmbH, RUBITHERM data sheet (2000). RUBITHERM GmbH, Hamburg, Germany.

[21] Hale DV, Hoover MJ, O’Neil MJ. (1975). Phase Change Materials Handbook. NASA CR 61363. 
[22] Rohsenow WM, Hartnett JP, Cho YI. (1998). Handbook of Heat Transfer. third ed. New York.

[23] Skoplaki E, Boudouvis A, Palyvos J. (2008). A simple correlation for the operating temperature of photovoltaic modules of arbitrary mounting. Solar Energy Materials and Solar Cells 92(11): 1393-1402. https://doi.org/10.1016/j.solmat.2008.05.016

[24] Evans D, Florschuetz L. (1977). Cost studies on terrestrial photovoltaic power systems with sunlight concentration. Solar Energy 19(3): 255-262. https://doi.org/10.1016/0038-092X(77)90068-8

[25] Chow TT. (2003). Performance analysis of photovoltaicthermal collector by explicit dynamic model. Solar Energy 75: 143-152. https://doi.org/10.1016/j.solener.2003.07.001

[26] Tiwari A, Sodha MS. (2006b). Performance evaluation of a solar PV/T system: A parametric study. Renewable Energy 31: 2460-2474. https://doi.org/10.1016/j.renene.2005.12.002

[27] Tonui JK, Tripanagnostopoulos Y. (2007a). Improved $\mathrm{PV} / \mathrm{T}$ solar collectors with heat extraction by forced or natural air circulation. Renewable Energy 32: 623-637. https://doi.org/10.1016/j.renene.2006.03.006

[28] Chow T. (2003). Performance analysis of photovoltaicthermal collector by explicit dynamic model. Solar Energy 75(2): 143-152. https://doi.org/10.1016/j.solener.2003.07.001

[29] Patankar S. (1980). Handbook on Numerical heat transfer and fluid flow. USA. Taylor \& Francis Group, LLC.

[30] Benlekkam M, Nehari D, Madani HI. (2017). Enhancement of the Thermal Regulation Performance of a Curved PV Panel. International Journal of Renewable Energy Research 7(2): 707-714.

\section{NOMENCLATURE}

$\begin{array}{ll}H, h & \text { Enthalpy, } \mathrm{J} . \mathrm{Kg}^{-1} \\ H e & \text { Convectif heat transfer coeficient, } \mathrm{W} \cdot \mathrm{m}^{-2} \mathrm{k}^{-1} \\ S & \text { Radiation source term, } \mathrm{J} \\ L & \text { Latant heat, } \mathrm{J} \cdot \mathrm{kg}^{-1} \\ C p & \text { Specific heat at constant pressure, } \mathrm{J} \cdot \mathrm{kg}^{-1} \cdot \mathrm{K}^{-1} \\ K & \text { Thermal conductivity, } \mathrm{W} \cdot \mathrm{m}^{-1} \cdot \mathrm{K}^{-1} \\ P & \text { Pressure, } \mathrm{Pa} \\ T & \text { Température, } \mathrm{K} \\ t & \text { Time, Mn } \\ I & \text { Insolation, W.m } \mathrm{m}^{-2} \\ G & \text { Gravitational acceleration, } \mathrm{m} \cdot \mathrm{s}^{-2} \\ A & \text { porosity function } \\ U & \text { Velocity component in the i-direction, } \mathrm{m} \cdot \mathrm{s}^{-1} \\ C & \text { Reflecting constant of melting front }\end{array}$

\section{Greek symbols}

$\beta$

A

$\mathrm{H}$

$\Gamma$

$\mathrm{P}$

$\mathrm{M}$

\section{Subscripts}

$\begin{array}{ll}\text { W } & \text { wind } \\ \text { Am } & \text { ambiant } \\ \text { se } & \text { sensible } \\ 0 & \text { Reference } \\ \text { m } & \text { Melting } \\ \text { S } & \text { Solidus } \\ 1 & \text { Liquidus } \\ \text { PV } & \text { Photovoltaic } \\ \text { C } & \text { Cell } \\ \text { T } & \text { Total }\end{array}$

Tilt angle,

Total
Thermal expansion coefficient, $\mathrm{K}^{-1}$

PV cell efficiency, \%

liquid fraction

Density, Kg.m ${ }^{-3}$

Dynamic viscosity, 